physiological chemistry, and the second part might quite well have formed the subject of a brief paper in one of the numerous journals devoted to such subjects. W. D. H.

Pages from a Country Diary. By P. Somers. Pp. vi +280 ; illustrated. (London: Edward Arnold, 1904.) Price $7 s .6 d$.

THIs is one of those delightful books written in the form of a discursive diary, somewhat after the style of Sir Herbert Maxwell's "Memories of the Months," which may be taken up and read during every spare half-hour until the reader finds with regret that he has come to the last page. Almost every kind of topic and pursuit connected with country life receives a share of attention, among them, to a brief extent, the habits and ways of birds and other animals. Among statements connected with natural history is one (on the authority of a well known taxidermist) that albino pheasants always have diseased liver; this, however, if true, can scarcely be cause and effect, since such birds have white plumage from the first, and they surely cannot be hatched with liver-disease. Special interest attaches to the statement that a hen grouse of normal colouring produced an entire brood of creamcoloured chicks, since this seems to afford an instance of how a new colour-phase might be produced by discontinuous variation. The subsequent history of the brood is not recorded-probably its members were all shot.

Several references are made to otters and their habits, and, although he is a thorough sportsman, the author cannot refrain from uttering a word of sympathy with these beautiful animals when surrounded in the water by a pack of hungry otter-hounds. On the other hand he has nothing but scorn for the sickly sentimentality of those who would forbid such manly sports as hare-hunting and stag-hunting, even when the deer is a so-called tame animal.

\section{A Scheme for the Detection of the more common} Classes of Carbon Compounds. By Frank E. Weston, B.Sc. Pp. viii +56 . (London : Longmans, Green and Co., Ltd., I904.) Price $2 s$.

THIs little book is intended for students who are preparing in chemistry for the final B.Sc. examination of the University of London. The author, who is lecturer on chemistry at the polytechnic in Regent Street, has elaborated the scheme now offered as the result of many years' experience with his own classes. There certainly has been a dearth of " systematic schemes " for the detection of carbon compounds, and from this point of view the book should be useful. Whether it will have any real educational value will depend very much upon the manner in which it is used. If, as in the case of the "systematic schemes" for the detection of inorganic substances, the identification of organic compounds is to be reduced to a purely mechanical series of operations involving no real scientific knowledge on the part of the student, the present book will do more harm than good to the cause of education, although it may help candidates through the final B.Sc. as intended. On the other hand, if used intelligently in connection with the scientific treatment of organic chemistry, it may be made of some educational use. The selection of compounds has on the whole been judicioušly made, and we have no fault to find with the treatment excepting to point out that certain crudities of style and inconsistencies of spelling seem to indicate either imperfect knowledge or imperfect revision. What quantity, for example, is meant by " a pinch"? Why should the word " monohydricphenols" appear on one page and " triNO. I 834 , VOL. 7 I] hydric phenols" on another? There are too many slips of this kind in such a small book to enable us to recommend it unhesitatingly to students in its present form.

Photograms of the Year 1904. By the Editors and Staff of the Photogram, assisted by A. C. R. Carter. Pp. xlviii $+x 76$. (London: Dawbarn and Ward, Ltd., I904.) Price 2s. net.

IN these pages we have typical photographic pictures of the year reproduced and criticised. This statement does not apply simply to British productions, but extends to those made in many lands where pictorial photography is practised. Robert Demachy discourses on the pictures exhibited at the annual series of photographic events in France. British Columbian progress is recorded by $\mathrm{H}$. Mortimer Lamb. The editor of the Australian Photographic Journal gives some notes of the advances made in his country, while "A new Departure in American Pictorialism" is written by Savakichi Hartmann. These are followed by articles on the work of the year, suggestions to would-be picture-makers by H. Snowden Ward, and " Royal and Ring." The two great exhibitions, the Photographic Salon and the Royal, are dealt with by A. C. R. Carter. The "American Salon" and "Western Workers in the United States " conclude the volume. It may be mentioned that this publication is the tenth annual issue, and equals, if it does not exceed, both in quality and number of illustrations, those that preceded it. Most of the reproductions are the work of Messrs. Carl Hentschel, Ltd.

It seems scarcely necessary to add that those of our readers who follow this special branch of photography will find in this volume material which should prove of great value to them.

\section{LETTERS TO THE EDITOR.}

[The Editor does not hold himself responsible for opinions expressed by his correspondents. Neither can he undertake to return. or to correspond with the writers of, rejected manuscripts intended for this or any other part of NATURE. No notice is taken of anonymous communications.]

\section{Heterogenetic Fungus-germs.}

THE development of brown fungus cells in connection with Zooglœa, as described in NATURE, November 24 , by Dr. Bastian, is very familiar to me, and probably to all who attempt pure cultures of fungi.

Various species of microscopic fungi belonging to the genus Cladosporium are everywhere present on fading and dead leaves. The spores, and also the vegetable portions of these fungi, constantly assume the form called Dematium pullulans by De Bary. Such forms produce exceedingly minute colourless conidia, which can pass through thick filter paper. Under normal conditions these minute conidia on germination form delicate hyaline hyphæ which give origin to a Cladosporium. If cultures of these conidia become infested with bacteria that form Zooglœa the hyphæ become invested with a comparatively thick, brown cell-wall, and form either compact masses of cells or irregular hyphæ consisting of short cells, constricted at the septa, exactly as shown in Dr. Bastian's Fig. I2. In a disease of Prunus japonica, caused by a Cladosporium, large masses of gum, just sufficiently dense to prevent dripping, issued from the wounds. The mycelium of the fungus spread into this gum, and produced myriads of brown cells arranged in chains.

The semi-liquid gum caused the same abnormal development as that produced by Zoogloea. A plate showing the entire course of development of the fungus in the gum is contained in the Kew Bulletin, December, 1898. As these fungi only develop on fading leaves, it was not to be expected that they would appear in infusions of young grass.

Herbarium, Kew.
George Massee. 